Categorizing Cruise Lines by Passenger Perceived Experience

By

Yiwei Li and Robert J. Kwortnik

Published in

The Journal of Travel Research (2017)

Vol. 56(7), 941-956

http://journals.sagepub.com/doi/abs/10.1177/0047287516674602 


\title{
Categorizing Cruise Lines by Passenger Perceived Experience
}

\begin{abstract}
In the travel and hospitality industries, categorization of products, brands, and experiences permit efficient comparison and evaluation that aids decision making-from consumer choice to organizational strategy. However, categories often involve self-categorization (e.g., marketer defined) that may not reflect the reality of dynamic markets and industries. In this study of the cruise industry, we derive a new categorization approach using consumer perceptions of their cruise experiences to challenge a long-standing industry typology. Results using a variety of statistical tests of J.D. Power data from more than 3,000 cruisers yield a new and more informative category structure and assignment of cruise lines to it. Analyses reveal differences between the new cruise categories in terms of determinants that influence customer choice. Discussion highlights benefits to travel practitioners of using dynamic and customer-based categories, as well as to researchers of applying advanced statistical techniques to expose unexpected and insightful patterns in secondary data.
\end{abstract}

Key Words: Cruise industry, Customer experience, Categorization, Marketing, Data Mining 


\section{Categorizing Cruise Lines by Passenger Perceived Experience}

The hospitality industry is replete with categories. Hotels are categorized by brand within chains (e.g., JW Marriott, Marriott, and Courtyard), by chain scale (e.g., luxury, upscale, and midscale), or by style of service (e.g., boutique, resort, and extended stay). Restaurants are similarly categorized (e.g., fine dining, casual dining, and quick service), as are airlines (major, national, and regional) and service/seating within airlines (first-class, business-class, and economy). The hospitality industry itself is a broad category within the service industry and encapsulates a set of supplier categories (e.g., lodging, transportation, and tourism).

Categories serve a variety of purposes. At a fundamental level, categories give structure to a set of stimuli to facilitate understanding, meaning, comparison, and evaluation (Allport 1954; Cohen and Basu 1987). For example, in the lodging industry, managers can use the chain-scale categories derived by STR Global to form competitive sets of hotels for comparison of pricing and occupancy performance. On the other hand, lodging marketers and consumers can use categories based on style of service to facilitate the matching of consumer needs with a type of hotel that will best satisfy those needs. These different categorical perspectives for the same stimuli highlight the need to view categorization dynamically and based on the requirements of the user. For example, the W Hotels brand of Starwood Hotels and Resorts had been categorized by the company as a boutique hotel since its inception; however, in 2014, Starwood began a rebranding campaign to categorize W Hotels as part of Starwood's luxury group. This categorical shift was driven in part by consumer perception of (and willingness to pay for) W Hotels as a luxury experience (Thomas 2014). To continue to position the $\mathrm{W}$ brand as a boutique 
hotel would limit the potential for growth and possibly confuse consumers who increasingly viewed W Hotels as more than just a boutique lodging experience.

The leisure cruise industry offers an untapped domain for examining the role and dynamic nature of organizational categorization —an area of emerging interest for management scholars (Vergne and Wry 2014). The cruise industry has experienced dramatic structural changes since the 1960s when jet travel shifted the core product from transportation to leisure travel. The industry grew quickly, with worldwide passenger volume increasing from half a million in 1970 to 23 million in 2015 (CLIA 2005; 2016); however, during the same period, the industry contracted from more than 100 companies to half as many and dominated by three cruise corporations: Carnival Corporation, Plc., Royal Caribbean Cruises, Ltd., and Norwegian Cruise Line Corporation, Ltd., which control most of the North American cruise market.

With the birth of the modern cruise industry in the 1970s, cruise marketers led by the industry's trade organization, Cruise Lines International Association (CLIA), promoted a categorization scheme to simplify the decision process for consumers and for travel agents, who were the main distribution channel and largely unfamiliar with the positioning differences of cruise brands. The four main categories of cruise line were contemporary (a label used by the industry to describe mass-market cruise lines), premium, luxury, and specialty (niche) (Gibson 2006; Kwortnik 2006). These categories are still used in the industry, with consensus as to the dimensions that distinguish each category (e.g., price level, service level, ship size, and target market). Kwortnik (2006) offered a description of each category and assignment of cruise lines to categories based on CLIA resources and cruise-line promotions (see Table 1). Notable, though, is that these categories are not empirically derived from customer perceptions, but are marketer created based on positioning strategy, product form, price levels, etc. 
Insert Table 1 Here

Since the year 2000, there have been major changes in the cruise industry in terms of product design and positioning. First, the demise of the budget cruise lines (e.g., Commodore, Premier, and Regal) left Carnival Cruise Lines as the low-price leader at the same time that the company was building new ships and improving quality (Kwortnik 2006). Other firms in the contemporary segment also introduced product and service upgrades that made them more similar to cruise lines in the premium category. For example, Royal Caribbean's introduction of the largest cruise ship in the world, Oasis of the Seas, in 2009 generated such strong demand that its prices were sometimes higher than those for sister-brand Celebrity Cruises for similar cabin types_-even though Celebrity was positioned as a premium brand. Similarly, companies in the premium category, especially newer entrants like Oceania, blurred the lines between premium and luxury categories (Jainchill 2010).

Despite these changes and market realities, the product-category structure used by cruiseindustry marketers is largely unchanged (Bjelicic 2012). The main purpose of this paper is to take a data-driven approach to assess cruise-line categories, but to do so taking into account the customers. Toward this end, this research used J.D. Power data from more than 3,000 cruisers who evaluated a recent cruise experience. Analysis featured a clustering procedure based on experience measures to determine which cruise lines are perceived by customers to be the most similar in terms of the experience delivered.

The contributions of this research are twofold. First, for industry practitioners, the findings show that the cruise industry is ripe for a new product typology that better matches 
cruise lines with customer perceptions — and raises the interesting question of whether product categories used in other hospitality sectors might benefit from customer-focused review as well. We argue that more valid categorization schemas benefit researchers, practitioners, and consumers by facilitating comparisons across organizations and industry structures. Second, the methodology used to mine the data highlight the insights that emerge when more powerful statistical techniques than typically used by industry analysts are applied to secondary data to uncover unexpected relationships. The hospitality industry is awash in data, giving scholars an unprecedented opportunity to apply methods that often are confined to academic journals to instead improve management understanding of the data for deriving insights that can aid decision making.

\section{Literature Review}

\section{Categorization}

Categorization is a fundamental cognitive process through which people simplify and order a complex world by assigning stimuli to categories based on their similarities and differences (McGarty 1999; Mervis and Rosch 1981). In daily life, we use categories to identify a related or dissimilar object, make rough judgments and decisions, and make predictions across a range of contexts - from the right category of wine to pair with a certain dish to the right category of travel for a certain occasion (Allport 1954).

Research takes three general views of categories: classical, probabilistic, and exemplar (Medin and Smith 1984; Rosch 1978; Smith and Medin 1981). The classical view posits that members in a category share defining properties and that categories have clear boundaries. The probabilistic or prototype view challenges the notion of definite features (Rosch and Mervis 
1975; Smith and Medin 1981) and assumes that categories are summary representations, with categorization as a process of assessing similarity rather than applying a definition (Medin and Smith 1984). Under this view, categories do not have clear boundaries, and membership in a category can be graded (i.e., more prototypical members have more characteristic features than less prototypical members) (Barsalou 1985; Rosch 1973). The exemplar view maintains that categories are represented by a set of individual exemplars that play the dominant role in discriminating new instances of the categories (Medin and Schaffer 1978; Reed 1972).

Despite a rich literature on categorization in cognitive and social psychology, studies of categorization in management and marketing were scant until the 1980s (Bettman and Sujan 1987; Cohen and Basu 1987; Porac, Thomas, and Baden-Fuller 1989). This is notable, because studying management activities within an industry typically demands the comparison of those activities in same or different categories, as well as the division of an industry into categories of organizations that resemble each other and compete to some extent. Furthermore, it is important to consider not only what organizations are included in which categories, but also how those categories were formed and for what purpose.

In their review of categorization in management studies, Vergne and Wry (2014) summarized two streams of research: a self-categorization view and a categorical-imperative view. The self-categorization view draws on cognitive psychology and examines how organizations categorize themselves (Porac and Thomas 1990; Porac et al. 1989; Porac, Thomas, Wilson, Paton, and Kanfer 1995). Self-categorization holds that organizations with common attributes see themselves as part of the same category and self-select into it (McNamara, Luce, and Thompson 2002). Moreover, categories are shaped by management action and organizational rivalries. For example, McDonald's marketers might try to re-categorize the brand 
from "quick-service” to "fast-casual dining” based on efforts to improve décor, service, and menu options. In contrast, the categorical-imperative view draws on sociology and examines how categories are imposed on organizations by the expectations of outside audiences (Zuckerman 1999). From this perspective, category membership and identity is externally defined, and organizations that do not conform to the codes, norms, and identity labels of external audiences may be considered not part of the category. For example, if consumers do not view McDonald's change efforts as sufficient—or if consumers' schema knowledge associated with McDonald's as a quick-service hamburger restaurant was pervasive, consumers would not acknowledge McDonald's as a member of the fast-casual category. For the purposes of the present study, marketer-defined categories represent the self-categorization view, whereas customer-derived categories represent the categorical-imperative view.

The process of categorization is dynamic and evolutionary (McGarty 1999; Mohlin 2014). To categorize organizations is to form rules for deriving category boundaries based on attributes that distinguish between categories - though these boundaries are often fuzzy and in flux depending upon competitive pressures (from the self-categorization view) or the changing needs and parameters of external audiences (from the categorical-imperative view). Both organizations and external audiences have limited attentional and cognitive resources and can make mistakes when judging category affiliation (Baum and Lant 2003; Porac et al. 1995). As such, categories proposed separately by organizations and audiences can be different for the same stimuli. Contested categorization typically involves an evolution to arrive at category structure and membership agreement. Since organizations and audiences may come to the categorization process with different purposes (i.e., an organizational purpose might be product positioning, whereas an audience purpose might be decision accuracy), unbalanced interactions between them 
drive modification of the category structure (Rao, Monin, and Durand 2005). This process becomes stable when organizations and audiences reach consensus on categories and members.

In the marketing field, a common means to solve categorization problems is competitor analysis, with either demand- or supply-oriented approaches (Rao and Steckel 1998). Demandoriented approaches follow the categorical-imperative view, defining competitor sets based on customer requirements. Demand-oriented methods include perceptual mapping, substitution inuse analyses, and brand-switching analyses. For example, a perceptual map visually represents consumers' perceptions and preferences for a given group of brands based on key product attributes. The distances between any two points on a perceptual map indicates the psychological similarity of the corresponding brands in the consumer's mind. In terms of the statistical methods for determining categories, cluster analysis, sometimes combined with multidimensional scaling, factor analysis, and discriminant analysis, is commonly used (Punj and Stewart 1983).

We employed the categorical-imperative perspective using attributes of the cruise experience to compare categories derived from customer feedback with the marketer-defined categories (see Figure 1). Under the self-categorization view, categories in the cruise industry are defined based on cruise lines' brand and marketing strategies. However, under the categoricalimperative view, categories are derived based on perceived experience that reflect similarities of delivered service among cruise lines. If discrepancies exist between marketer-defined categories and customer-derived categories, a stable category structure has not been reached. Our study compares the two categorization approaches in terms of structure and membership, as well as informational value; i.e., which categorization provides better information about the relationship between categories and experience dimensions that form the categories, determinants of category choice, and post-experience cruiser behavior. 
Insert Figure 1 Here

\section{The Cruise Experience}

Scholars and industry observers suggest that consumers in the experience era (Pine and Gilmore 1999) seek more than just satisfying products and services, but also unique, memorable experiences (Arnould and Price 1993; Curtin 2006; Kozinets 2002). Some researchers refer to customer experience in terms of outcomes - the sensorial, emotional, cognitive, and behavioral effects obtained from interaction with external stimuli (Brakus, Schmitt, and Zarantonello 2009; Meyer and Schwager 2007). Other researchers view customer experience as a dynamic process of interaction (Grewal, Levy, and Kumar 2009; Pine and Gilmore 1999; Verhoef et al. 2009). Still other researchers apply a phenomenological view of experience defined largely by the objective characteristics of stimuli with which the person engages. For example, in the tourism context, Hanefors and Mossberg (1999) found that the overall experience and the perception of service quality of a tour are influenced by experiences with the various ingredients of the tour product. We adopted this phenomenological perspective to examine how cruise lines differ in terms of experiential elements that research indicates are core components of the overall cruise experience. Such elements include the food or dining experience (Josiam, Huang, and Spears 2009; Moscardo and Pearce 2003), stateroom experience, entertainment experience (Hosany and Witham 2010), excursion experience (Johnson 2006), and service experience (Josiam et al. 2009). We use these experiential elements as the primary inputs to the categorization model.

\section{Cruise Determinants}


Travel determinants are factors that influence consumer choice among alternatives and are commonly split into two types: internal and external (Crompton 1992; Decrop and Snelders 2005; Woodside and Lysonski 1989). Internal factors are individual characteristics of decision makers that influence or moderate their travel choices, including age (Smith and Mackay 2001), cultural background (Awaritefe 2005), party composition (Kang and Hsu 2005), and motivations (Hill, McDonald, and Uysal 1990). External factors are the features of service providers, such as price (Nicolau and Mas 2006), brand (Murphy, Benckendorff, and Moscardoa 2007), distance or location (Ormiston, Gilbert, and Manning 1998), safety (Sirakaya, Sheppard, and McLellan 1997), travel agents' recommendations (Hudson, Snaith, Miller, Hudson 2001; Klenosky and Gitleson 1998), and service quality levels (Kim, Holland, and Han 2013).

Research also reveals all manner of travel determinants based on the decision context, such as resorts (Brey et al. 2008) or ski destinations (Konu, Laukkanen, and Komppula 2011). Consistent with research on general travel and tourism determinants, cruise determinants comprise internal (of the cruiser) and external (of the cruise provider) factors that may influence the cruiser's choice of cruise line. For example, Lee and Yoo (2015) identified a number of external factors that influence cruiser choice, including trip duration, stateroom, onboard activities, itinerary, excursions, and crew service. CLIA (2014) summarized the top 10 factors influencing North American cruiser choice: destination, price, opportunity to relax, unique experience, convenience, particular cruise ship, sightseeing opportunities, availability, cruise length, and programs for family and children, all external factors that reflect a marketerconceived view of cruise determinants.

\section{Research Questions}


Our study was data-driven and shaped by the questions asked in the J.D. Power cruise line satisfaction survey. Our main objective was to apply the categorical-imperative view to identify a customer-derived categorization scheme for the primary cruise lines serving the North America market based on passenger-perceived cruise experience, and to compare this category structure with the current marketer-defined category structure. In pursuit of this goal, we addressed four main research questions, leading with the first overarching question:

Research Question 1: Do the marketer-defined and customer-derived approaches for categorizing cruise lines yield the same categories and membership in these categories?

Based on marketer-defined cruise line categories, past research suggests that the relative importance of cruise experience elements will differ across cruise line categories. Kwortnik (2006) proposed that underlying the marketer-defined categories are the benefits customers seek from the experiences offered by cruise lines. For example, cruisers who prefer contemporary cruise lines seek abundant and varied food and activities, whereas cruisers who prefer premium cruise lines seek more refined dining and more sophisticated service. Our second research question addresses the components of cruise experience and categorization.

Research Question 2: Do elements of the cruise experience contribute equally to the overall experience across customer-derived cruise line categories?

The cruise product is described as having high levels of customer behavioral loyalty (Petrick 2004), though for some brands, this loyalty may be more to the cruise experience than to the brand itself (Applegate, Kwortnik, and Piccoli 2005). Intuitively, the impact of cruise experience on cruiser loyalty should be stronger for cruise lines that provide better experiences.

Research Question 3: Is the effect of cruise experience on cruiser behavioral loyalty the same across different customer-derived cruise line categories? 
Research has found that travelers in the same market segment weigh certain factors as more important when they choose destinations and tourism brands (Swarbrooke and Horner 2007). However, research has not examined the association between cruise determinants and customer-derived cruise line categories. In the present study, we compared the association of cruise determinants with marketer-defined categories vs. customer-derived categories.

Research Question 4: Are cruise determinants associated with specific cruise line categories? If so, which categorization approach (marketer-defined or customer-derived) better explains this association between determinants and categories?

\section{Method}

\section{Sample}

The sample for this research comes from the J.D. Power 2013 Cruise Line Satisfaction Study, which yielded data from 3,003 cruisers who completed an online questionnaire. The cruisers were recruited from a consumer panel between May 29 and June 12, 2013 and were identified by a screener question that asked if they had taken a cruise from April 2012 to March 2013. Respondents were asked about their latest cruise experience aboard one of seven cruise lines: Carnival $(n=671)$, Royal Caribbean $(n=639)$, Norwegian $(n=515)$, Princess $(n=318)$, Disney $(n=314)$, Celebrity $(n=296)$, and Holland America $(n=250)$. These cruise lines capture 64.7\% worldwide market share and more than 95\% share of the North America market, which produces $60.2 \%$ of the worldwide passenger volume (CLIA, 2014).

\section{Measures}


The J.D. Power survey contained 24 questions across 5 areas: 1) cruiser choice behavior (described below); 2) cruise decision factors (e.g., information sources, booking channel, cruise determinants, price paid); 3) cruise communication (e.g., customer contact for questions/ problems, company problem resolution); 4) cruise experience (e.g., perceptions of the cruise and its elements); and, 5) cruiser behavioral loyalty (e.g., repurchase and recommendation intentions). For this study, we used questions related to cruiser choice behavior, cruise decision determinants, cruise experience, and cruiser behavioral loyalty for analysis.

Cruiser choice behavior was measured with 4 items: 1) Cruise line selected (from a list of cruise lines); 2) Month of cruise travel; 3) Cruise duration in days; 4) Number of passengers staying in the respondent's stateroom. We primarily used these measures as controls in the analysis. Cruise determinants was measured by asking respondents which of 11 factors influenced their selection of the cruise line they most recently sailed on, including price, brand reputation, past experience with the brand, positive reviews, availability, entertainment, recommendations from a travel agent, itinerary, sail dates, casual cruising, and trip length.

The cruise experience was measured with single items across seven experience domains using a 10-point scale (1 = Unacceptable, 10 = Outstanding): 1) Embarkation experience, described as the experience of getting on and off the ship during the cruise; 2) Food experience, with ratings of dining rooms, buffets, room service, etc.; 3) Entertainment experience, capturing professional entertainment, organized activities, and similar amenities; 4) Cost experience, including perceptions of the cruise fare price and onboard charges; 5) Service experience provided by company representatives and onboard staff/crew; 6) Excursion experience, which included sightseeing options and associated transportation (excursion experience had missing values for $30.9 \%$ of the cases; because not all cruise customers buy excursions, we deleted this 
variable from further analyses); and, 7) Stateroom experience, described as the experience with size, design, coziness, and convenience of the stateroom.

Cruiser behavioral loyalty was measured with 2 questions: "How likely are you to take another trip with [the cruise line]" and "How likely are you to recommend [the cruise line] to friends, relatives or colleagues.” Both questions used 4-point scales, where 1 = definitely will not and 4 = definitely will.

Scores on the experience measures were highly left skewed, with few respondents reporting bad experiences. To conduct robust statistical analyses, variable transformation was needed (Fink 2009). Outlier analysis revealed that scores originally below 5 were all extreme values. We applied the Winsorization approach for dealing with outliers (Aguinis, Gottfredson, and Joo 2013), which involves replacing extreme values with a specified percentile of the data, in this case, replacing all values originally below 5 with 5 , which was the 5 th percentile of the data and also the closest non-outlier. After adjustment, the 10-point scales became 4-point scales. We labeled original values 1 through 5 as 1 (weak), 6 and 7 as 2 (acceptable), 8 and 9 as 3 (good), and 10 as 4 (excellent). The resulting transformation produced scores that were more centrally distributed. After transformation, the six experience variables showed high construct reliability (Cronbach's alpha $=0.893, \mathrm{CR}=0.894$, and AVE $=0.585)$ and convergent validity $(6$ variables loaded on a single factor with loadings from 0.719 to 0.817 ).

Insert Table 2 here

\section{Analysis}


To address the research questions, we used the K-means clustering method. Compared with a hierarchal clustering method, K-means clustering is more effective when a priori information is available to suggest a specified number of expected clusters (Brogen and Barnett 1987; Everitt, Landau, and Leese 2001), as is the case with the marketer-defined categorization approach used in cruise industry. To address the second and the third research questions, we used multi-group structural equation modeling to examine if a unified cruise experience in terms of cruise elements exists across categories. Next, we used multi-group structural regression models to test the relationships between cruiser experience and cruiser behavioral loyalty among all categories. Lastly, we used crosstab analyses and Cochran Armitage trends Z tests to examine the association between cruise determinants and cruise line categories.

\section{Results}

\section{RQ1: Cruise Line Categorization}

Marketing practitioners categorize the seven cruise lines in this study into one of two groups based on brand and marketing strategies: contemporary or premium. Carnival, Disney, Norwegian, and Royal Caribbean are typically categorized as contemporary brands; Princess, Celebrity, and Holland America are categorized as premium brands (Kwortnik 2006). To explore this categorization structure we first conducted a K-means cluster analysis where K equals 2, contemporary or premium categories. We used the six factors in the cruise experience measure as clustering variables. Interestingly, we found that Disney belonged to neither contemporary nor premium categories. Disney, which had high customer-experience scores formed one group by itself, and the six other cruise lines formed a second group. We then conducted a K-means cluster analysis where K equals 3. As shown in Table 3, Norwegian, Princess, and Carnival were 
in the first category; Celebrity, Holland America, and Royal Caribbean belonged to a second category; and Disney still formed a third category alone.

\section{Insert Table 3 Here}

ANOVA tests (see Table 4) revealed that the differences in the means of the six experience variables and the overall experience score among the three customer-derived cruise line categories were all significant (F-values were between 8.216 and 32.380 and all p-values were below 0.001). Tukey HSD tests showed that the difference in overall experience scores between any two categories was significant. These tests indicated that the three customer-derived cruise line categories were significantly different from each other; in other words, the cruise experience differences between categories are meaningful. Interestingly, the two marketerdefined cruise line categories showed a significant difference in only one of the six experience factors (entertainment experience) and no difference in overall experience scores. These results indicated that the customer-derived cruise line categorization is more informative than the marketer-defined categorization.

\section{Insert Table 4 Here}

Based on cruiser-perceived experience, we found a more informative categorization structure that differed from the generally accepted tiers of cruise lines defined by marketers. Carnival and Norwegian (“contemporary” brands) were grouped together, as expected—but Princess (positioned as a "premium" brand) was rated as providing an experience more like the 
contemporary brands than the premium brands. We tentatively call this first category (category a) "standard.” Celebrity and Holland America (“premium” brands) were grouped together, as expected—but Royal Caribbean (positioned as a "contemporary” brand) joined their ranks in terms of customer experience. We retain the "premium" label for this second category of cruise lines (category b). Finally, Disney (positioned as a “contemporary” brand) stands alone in terms of cruise experience, being perceived as better than not only the contemporary brands, but even the premium brands, so we tentatively label this third category (category c) as "extraordinary." Our answer to Research Question 1, then, is that the disagreements between marketer-defined and customer-derived categories suggest that the conventional industry categorization for cruise lines is unstable and needs updating to more accurately reflect the experiences cruisers perceive.

\section{RQ2: Cruise Experience across Customer-Derived Categories}

To explore if the relative contribution of cruise experience elements to the overall experience is the same across different cruise line categories, we built multi-group structural equation measurement models (Figure 2) with different constraints on loading weights, $\mathrm{W}_{\mathrm{ki}}$, where $\mathrm{k}=\{2,3,4,5,6\}$ represents the loading path number and $\mathrm{i}=\{\mathrm{a}, \mathrm{b}, \mathrm{c}\}$ is the category number. For example, $W_{3 b}$ is the loading weight of entertainment experience for category $b$ (premium) cruise lines. The first measurement model was the unconstrained-loading measurement model (ULM), setting no constraints on $\mathrm{W}_{\mathrm{ki}}$ thus assuming the contribution of cruise elements to the overall experience is independent of cruise line categories. Partially constrained-loading measurement models (PCL) assumed that the contribution of cruise elements to the overall experience is the same between two cruise line categories, but different from that of the third category. For example, by setting constraints $\mathrm{W}_{\mathrm{ka}}=\mathrm{W}_{\mathrm{kb}}$, PCL1 assumed that the 
combination of cruise experience elements is the same between category a (standard) and category b (premium) cruise lines, but that of category c (extraordinary) cruise lines is different. Similarly, PCL2 constrained $\mathrm{W}_{\mathrm{ka}}=\mathrm{W}_{\mathrm{kc}}$, and PCL3 constrained $\mathrm{W}_{\mathrm{kb}}=\mathrm{W}_{\mathrm{kc}}$. The equal-loading measurement model (ELM) assumed a general set of cruise experience elements that applies to all cruise line categories. Thus, in this model $\mathrm{W}_{\mathrm{ka}}=\mathrm{W}_{\mathrm{kb}}=\mathrm{W}_{\mathrm{kc}}$.

Insert Figure 2 Here

We randomly selected 300 responses from each cruise line category, making sure that the sample sizes of all groups in the multi-group structural equation models were even to make the results more robust. We did not constrain the variances of unobservable variables. The key goodness of fit indices of each model are shown in Table 5. The results suggested that all models meet the commonly used standard (Kline 2009) on most indices (RMSEA $\leq 0.05$; GFI $\geq 0.95$; AGFI $\geq 0.90 ; C F I \geq 0.95)$, except for the $p$ value of the $\chi^{2}$ test ( $\left.p \geq 0.05\right)$, thus indicating all models have good fit. The $\chi^{2}$ value of PCL2 is the smallest among the three partially constrained models, indicating that PCL2 is the best partially constrained model.

Insert Table 5 Here

The AIC values suggested that the ELM is the best measurement model with the smallest AIC. We confirmed this by comparing models using $\chi^{2}$ tests (Table 6). Comparing the ULM and PCL2 models, the p value of the $\chi^{2}$ test exceeded 0.05, indicating that PCL2 is no worse than the ULM. Based on the principle of parsimony, the model with higher degrees of freedom (PCL2) is 
better. Similarly, the ELM is better than PLC2, because the p value of the $\chi^{2}$ test for this comparison is 0.608. Therefore, we concluded that the ELM is the best measurement model, meaning that the measured cruise experience elements all contribute to the overall experience for all cruise line categories. By comparing the unstandardized estimates of loading weights in Table 7, we found that food and entertainment experiences contribute the most to the overall cruise experience, while cost and embarkation experiences are less important.

Insert Table 6 and Table 7 Here

\section{RQ3: Cruise Experience and Cruiser Behavioral Loyalty}

To examine whether the effects of cruise experience on behavioral loyalty are the same across cruise line categories, we built multi-group structural regression models (Figure 3) on the basis of the equal-loading model (ELM). The key was to determine if the regression weights from cruise experience to behavioral loyalty $\left(\mathrm{W}_{7 \mathrm{i}}\right)$ are the same across cruise line categories. An important assumption we made was that the loading weights of the measurement models (Figure 3) were the same across categories, so we restricted $W_{k a}=W_{k b}=W_{k c}$, where $k \in\{2,3,4,5,6,8\}$ is the loading path number. This was based on the results from RQ2 and because the model constraining all categories to have equal-weight loadings of intent to return on behavioral loyalty $\left(\mathrm{W}_{8}\right)$ best fit the data. We again did not restrict variances of latent variables in the models.

Insert Figure 3 Here 
The first model was the unconstrained-loading structural regression model (ULSR), which does not impose restrictions on the regression weight, $\mathrm{W}_{7 \mathrm{i}}$, and assumed different effects of cruise experience on behavioral loyalty for the cruise line categories. PCL4 through PCL6 were the partially constrained-loading models. PCL4 constrained $\mathrm{W}_{7 \mathrm{a}}$ to equal $\mathrm{W}_{7 \mathrm{~b}}$, forcing the effect of cruise experience on behavioral loyalty of category a (standard) and category b (premium) cruise lines to be the same, which is different from that of category c. Similarly, PCL5 restricted $W_{7 a}$ to equal $W_{7 c}$, and PCL6 restricted $W_{7 b}$ to equal $W_{7 c}$. The last model was the equal-loading structural regression model (ELSR). It forced $\mathrm{W}_{7 \mathrm{a}}=\mathrm{W}_{7 \mathrm{~b}}=\mathrm{W}_{7 \mathrm{c}}$, assuming that the effects of cruise experience on behavioral loyalty are the same for all three cruise line categories.

Except for the p-value of the $\chi^{2}$ test, all other goodness of fit indices met acceptable standards (RMSEA $\leq 0.05 ; \mathrm{GFI} \geq 0.95 ; \mathrm{AGFI} \geq 0.90 ; \mathrm{CFI} \geq 0.95$ ), indicating that all models fit the data well (see Table 5). The $\chi^{2}$ values suggested that PLC6 was the best among the three partially constrained models. AIC values also suggested that PCL6 was the best model with the smallest AIC. Model comparisons based on the $\chi^{2}$ test shown in Table 6 further confirmed that PCL6 best fit the data. In the test comparing ULSR to PCL6, the p-value was larger than 0.05 , indicating that PCL6 was not worse than ULSR. On the basis of the parsimony principle, PCL6 is a better model with higher degrees of freedom. However, when comparing PCL6 with ELSR, the $\chi^{2}$ test yielded a p-value smaller than 0.05 , demonstrating ELSR was significantly worse than PLC6. Therefore, PCL6 was the best structural regression model.

The weight estimates in Table 7 were all positive, confirming a positive relationship between cruise experience and cruiser behavioral loyalty. However, we interestingly found that the estimate of $\mathrm{W}_{7 \mathrm{a}}$ is larger than the estimate of $\mathrm{W}_{7 \mathrm{~b}}$ and $\mathrm{W}_{7 \mathrm{c}}(0.711$ vs. 0.481$)$, indicating that 
the impact of cruise experience on behavioral loyalty for category a (standard) cruise lines is stronger than that for category b (premium) and category c (extraordinary) cruise lines.

\section{RQ4: Cruise Determinants and Customer-derived Cruise Line Categories}

To address the fourth research question, we conducted crosstab analyses to measure the association between cruise determinants and customer-derived cruise line categories. In the first crosstab (Table 8), cruise determinants were the dependent variable with 11 levels, and cruise category was the independent variable with 3 levels. The 3,003 survey respondents identified those determinants from the list of 11 options that influenced their cruise line choice, producing 10,524 selections in total, or 3.5 on average (for the three categories respectively, the average number of determinants identified was approximately 3.5 as well). Among the 11 determinants, price, reputation, past experience, itinerary, sail dates, and trip length were the most common influences on cruise line choice with more than 1,000 responses. The column percentages in parentheses indicated the proportion of times that a certain determinant was selected among all determinants in a given cruise category. For example, price represented $15.77 \%$ of the total determinants identified by respondents who chose the category a (standard) cruise lines, $13.62 \%$ of the total determinants identified by respondents who chose category b (premium) cruise lines, and $11.44 \%$ of the total determinants identified by respondents who chose the category c (extraordinary) cruise line. Another way to interpret these ratios is by multiplying the column percentages by 3.5 (the average number of determinants identified across categories), which revealed that approximately $55 \%$ of cruisers of standard cruise lines, $48 \%$ cruisers of premium cruise lines, and $40 \%$ cruisers of the extraordinary cruise line identified price as a choice determinant (note: these approximations are close to the exact values, which were $56.6 \%, 48.3 \%$, 
and 39.8\% respectively). From these results, we can infer that cruisers who chose standard cruise lines cared more about price as a decision factor than did cruisers who chose cruise lines from the premium or extraordinary categories.

The relationship between cruise determinants and cruise category—and the informational value of the customer-derived category structure-are further illustrated by the $\chi^{2}$ values in Table 8. The overall association between determinants and the customer-derived cruise line categories was confirmed by the total Pearson $\chi^{2}$ value of $273.12(\mathrm{p}<0.001)$. The sum $\chi^{2}$ column in Table 8 showed that eight cruise determinants were significantly related to cruise line category, while three (availability, recommendation, and trip length) were not, as their corresponding $\chi^{2}$ values were small (1.22, 3.91, and 3.19 respectively).

\section{Insert Table 8 Here}

Additional information can be gleaned about cruise determinants and category structure when considering RQ1 and the finding of significant differences in overall experience levels across the three categories. Based on the experience-level pattern of the customer-derived cruise line categories and the logic that the higher values represented better overall cruise experiences, we changed the independent variable (category) from categorical to ordinal, coding standard as 1 , premium as 2, and extraordinary as 3 . We then conducted 11 Cochran Armitage trends Z tests. The last column in Table 8 shows that of the 8 determinants associated with customer-derived categories, 7 are linearly related to the experience level of each category, except for past experience (cruisers on premium cruise lines used past experience the most in their cruise choice). $\mathrm{Z}$ values less than -1.96 revealed a negative linear relationship between the cruise experience level and price $(\mathrm{z}=-4.21)$, itinerary $(\mathrm{z}=-2.70)$, sail dates $(\mathrm{z}=-3.16)$, and causal 
cruising $(z=-3.68)$, indicating that cruisers who chose cruise lines in the category with lower experience levels were more likely to take price, itinerary, sail dates, and casual cruising into account when making decisions about cruise brands. In contrast, positive $\mathrm{Z}$ values larger than 1.96 indicated a positive linear relationship between the cruise experience level and reputation ( $\mathrm{z}$ =6.86), positive reviews $(z=3.60)$, and entertainment $(z=6.56)$; cruisers on cruise lines with higher experience levels were more likely to consider these factors when choosing a cruise line.

To confirm which categorization, the marketer-defined or customer-derived, is more informative, we repeated the crosstab analysis by using cruise determinants as the dependent variable and marketer-defined cruise line categories as the independent variable with only two levels, contemporary and premium. As shown in Table 9, 6 associations were significant between cruise determinants and marketer-defined cruise line categories (as compared to 8 significant associations when using the customer-derived structure). Surprisingly, several of the 6 associations between cruise determinants and marketer-defined cruise line categories were opposite to the relationships revealed using customer-derived categories-and in contrast to what one would expect intuitively. For example, results in Table 9 suggest that cruisers who chose premium cruise lines identified price and sail date more often as decision determinants, whereas cruisers who chose contemporary cruise lines identified reputation, positive review, and entertainment more often. In sum, these tests involving cruise determinants indicated that a categorization scheme based on customer-derived categories is more informative than one based on marketer-defined categories.

Insert Table 9 Here

\section{Discussion}


For the seven largest cruise lines serving North America, marketers in the cruise industry have long used two main categories, contemporary and premium, as part of a simple typology for describing what cruise brands offer in terms of service, style, amenities, price, etc. Carnival, Norwegian, Royal Caribbean, and Disney have been categorized as contemporary cruise lines, providing quality service, abundant food, and various activities on large ships to the mass market; Celebrity, Holland America, and Princess have been categorized as premium cruise lines, providing high-quality service, fine dining, and more sophisticated entertainment on mediumsize ships to a more selective market. But this marketer-defined categorization (selfcategorization) precludes the perspective of actual cruisers. Our study, using customer data from the J.D. Power 2013 Cruise Line Satisfaction Study, suggests that conventional industry categorization no longer reflects the cruiser experience and that a new category structure, one based on customer perceptions of the cruise experience, is warranted.

Specifically, using a categorical-imperative view, we found a different, three-level category structure by modeling the cruise experience in term of six experiential elements: embarkation, food, entertainment, costs, service, and stateroom. We proposed tentative labels for the three categories: 1) standard; 2) premium; and, 3) extraordinary. Analysis revealed that Carnival and Norwegian are members of the standard category, as expected, but are joined by Princess, a brand that had been considered premium by marketer-defined standards. Customers, however, rated Princess as providing an experience more like other standard brands than premium brands. The new premium category contains Celebrity and Holland America as expected, but Royal Caribbean joined their ranks in terms of an elevated customer experience. Finally, Disney stood alone, being perceived as providing an experience different than not only the contemporary (standard) brands, but even the premium brands. The disagreements between 
marketer-defined and customer-derived categories suggest not only that the category structure of the cruise industry has evolved, but so has organizational membership.

Additional analyses indicated that customer-derived categorization is more informative. First, the differences in cruise experience scores between the three customer-derived cruise line categories were significant, while the differences in experience scores between the marketerdefined categories were not. We also found that, based on customer-derived categorization, the combination of cruise experience elements that form the overall cruise experience was the same across categories, with food and entertainment experiences contributing the most. This finding suggests that cruise lines seeking to improve the overall experience-and perhaps to reposition to a higher-level category (e.g., from standard to premium, as Royal Caribbean did), should focus on enhancing dining and entertainment. Our study also found that the impact of cruise experience on behavioral loyalty was the strongest for standard-category cruise lines, which suggests that Carnival, Norwegian, and Princess are most likely to gain loyal customers by maintaining or improving the overall cruise experience.

The greater informational value of a new customer-derived categorization is further revealed by analysis of the association between cruise determinants and cruise line categories: of the 11 determinants measured in the J.D. Power survey, 8 are significantly associated with customer-derived categories, whereas 6 are significantly associated with the marketer-defined categories. We found that cruisers identify, on average, 3.5 determinants that influenced their choice of cruise line and that the influence of specific determinants varies across categories. For example, cruisers who chose standard cruise lines identified price and a casual cruise experience as affecting their decision more often than did cruisers who chose premium brands; on the other hand, cruisers who chose premium cruise lines identified itinerary and company reputation as 
affecting their decision more often than did cruisers who chose standard brands-findings that have face validity. It is notable that these associations are not constrained by specific category membership, but instead reflect the experience-level of the category, which demonstrates that the customer-derived categorization is more flexible for assigning members to categories.

From a practitioner perspective, the better informational value and greater flexibility of customer-derived categories offers insight for brand and product management. For example, a brand such as Princess Cruises that would be re-categorized from premium to standard might take advantage of this change by positioning against other standard brands (Carnival and Norwegian), especially if there are competitive advantages to doing so. Or, Princess's brand team may want to examine why customers perceive the brand as standard and not premium based on experiential factors. Perhaps the brand's dining and entertainment experiences have not kept pace with premium cruise lines and are now viewed as merely standard for the industry. Princess's brand managers would also need to be aware that the categorical shift from premium to standard means that certain cruise determinants (e.g., price, sail dates, and casual cruising) are more important to potential cruisers than reputation, positive reviews, and entertainment. On the other hand, a brand like Royal Caribbean that cruisers perceive to provide an above-standard (i.e., premium) experience, can be repositioned to compete with cruise lines in that category (e.g., Holland America and Celebrity)—and to earn associated price premiums. This would be akin to the W Hotels repositioning described earlier, though in that case, higher prices that guests were willing to pay for the $\mathrm{W}$ experience begat a strategic re-categorization of the hotel as a luxury brand; for Royal Caribbean, re-categorization and re-positioning as a premium experience opens the door to a premium-pricing strategy, especially if price is a less salient determinant for 
cruisers who choose premium cruise experiences. Instead, Royal Caribbean can spotlight those determinants that do matter to premium cruisers, such as entertainment and brand reputation.

Consumers, especially novice cruisers such as those in the fast-growing emerging economies (e.g., China), will also benefit from a new categorization scheme that better reflects the experience delivered. The cruise product is complex and costly, which is a main reason that potential customers rely on travel agents and not just online research to guide the decision process. The availability of more accurate and informative cruise categories and associated brand membership offers consumers an industry snapshot for developing a consideration set of product alternatives, as well as a short-hand for product comparison and evaluation. Such information should yield better decisions by matching experiences desired with experience-based categories, and ultimately lead to more satisfied customers.

\section{Contributions, Limitations and Directions for Future Research}

The main contributions of our study are twofold. First, we created a typology that better categorizes cruise lines, and we argued that this new category structure and assignment of cruise lines to it offers valuable new information for cruise practitioners and customers-both travel agents and cruisers themselves. In deriving the typology, we advance theory in the domain of categorization, in particular organizational categorization (see Vergne and Wry 2014), by contrasting two views—-self-categorization and categorical imperative—-to show that the latter yields a more valid and informative structure, especially in a dynamic context like the cruise industry. Using data from customers based on their actual cruise experiences, we built categories that impose their perceptions on the typology (the categorical imperative approach). We showed that this structure with "standard," "premium," and "extraordinary" categories better fits the data 
than the typology created by cruise marketers using a self-categorization approach. This is not to say that the marketer-defined approach lacks utility and should be jettisoned, rather that it should be updated to reflect the evolution of the industry, both in terms of organizations and consumers.

We acknowledge that the proposed typology, like many categorization schemes, is a blunt instrument that may not reflect within-brand product variation, such as between older and newer ships, and the consequent differences in experience these variations produce. Future research that applies a categorical-imperative approach using customer experience, but at the ship level, might identify a category structure that depends less on brand differences and more on some other dimension, such as degree of product innovation across brands. Furthermore, because the data used for the study did not contain customer perceptions of smaller luxury or specialty cruise brands, additional research is needed to expand the coverage of the industry and for testing the robustness of the typology.

The second main contribution of this study is the translation of the categorical-imperative approach into a methodology that used cluster analysis, multi-group structural modeling, and multi-group structural regression analysis for mining the J.D. Power data to reveal unexpected relationships and to produce insights far richer than the descriptive statistics relied on by industry analysts. The travel and hospitality industries are flush with data, from booking channels used and prices paid for travel products to post-consumption satisfaction scores and consumer reviews. However, analysis of this data typically yields summary statistics and performance reports that tell managers how the company is doing, but not necessary why the company is performing as it is or what can be done about it. The emerging field of business intelligence requires application of more advanced and robust analytic procedures to ask new questions of the data (i.e., how 
might cruise lines be categorized from the customer’s perspective as opposed to the marketer's) and to mine for interesting patterns and relationships.

Scholars have much to offer industry in guiding business intelligence, even if just encouraging managers to challenge the assumptions and conclusions of the reports they read. Indeed, the data-driven methodology used here to derive the new cruise typology suffers from the limitations typically associated with research that relies on data mining and post-hoc conclusions. The data were not collected to test theory, nor were the data readily adaptable for this purpose given the fixed survey design and select constructs measured. The measures were also not created based on theory or psychometric principles to better ensure validity and reliability. One obvious outcome of this measurement deficiency is that some scales produced variables with highly-skewed distributions that required transformation that may have introduced systematic error into the analysis.

These contributions and limitations underscore the opportunity for academic scholars to work with industry researchers to develop surveys and other data collection instruments that emerge from theory and that use constructs and measures which are valid and reliable. Such collaborations can also involve the application of advanced statistical methods that comprise the toolkit of academic researchers but that may be unknown to or little used by industry practitioners. As this study reveals, such statistical sleuthing can reveal surprising and useful insights such as new organizational categories that are fundamental to both academic research and industry strategy. Given the many and varied categories used in the travel and hospitality industries, continued investigation into the dynamics of organizational categorization is a fruitful area for future research. 


\section{References}

Aguinis, H., Gottfredson, R. K., and Joo, H. 2013. “Best-Practice Recommendations for

Defining, Identifying, and Handling Outliers.” Organizational Research Methods 16 (2): 270301.

Allport, G. W. 1954. The Nature of Prejudice. Reading, MA: Addison-Wesley.

Allsop, D. T., B. R. Bassett, and J. A. Hoskins. 2007. "Word-of-Mouth Research: Principles and Applications.” Journal of Advertising Research 47 (4): 398-411.

Applegate, Linda M., Robert J. Kwortnik, Jr., and Gabriele Piccoli. 2005. “Carnival Cruise Lines.” Harvard Business School Case Series 9-806-015.

Arnould, E. J., and L. L. Price. 1993. "River Magic: Extraordinary Experience and the Extended Service Encounter.” Journal of Consumer Research 20 (1): 24-45.

Awaritefe, O. D. 2005. “Image Difference between Culture and Nature Destination Visitors in Tropical Africa: Case Study of Nigeria.” Current Issues in Tourism 8 (5): 363-393.

Barsalou, L. W. 1985. “Ideals, Central Tendency, and Frequency of Instantiation as

Determinants of Graded Structure in Categories.” Journal of Experimental Psychology: Learning, Memory, and Cognition 11(4): 629-654.

Baum, J. and T. Lant. 2003. “Hits and Misses: Managers’ (Mis)categorization of Competitors in the Manhattan Hotel Industry.” In Geography and Strategy (Advances in Strategic Management, Volume 20), edited by J. Baum and O. Sorenson, 119-156. Bingley, UK: Emerald Group Publishing.

Beck, J. 2007. “The Sales Effect of Word Of Mouth: A Model for Creative Goods and Estimates for Novels.” Journal of Cultural Economics 31 (1): 5-23. 
Bettman, J. R. and M. Sujan. 1987. "Effects of Framing on Evaluation of Comparable and Noncomparable Alternatives by Expert and Novice Consumers.” Journal of Consumer Research 14(2): 141-154.

Bjelicic, B. 2012. “Development of the Cruise Industry Structure - the Supply Side.” In The Business and Management of Ocean Cruises, edited by M. Vogel, A. Papathanassis, and B. Wolber, 19-29. Cambridge, MA: CAB International.

Borgen, F. H. and D. C. Barnett. 1987. “Applying Cluster Analysis in Counseling Psychology Research.” Counseling Psychology Research 34(4): 456-468.

Brakus, J., B. Schmitt and L. Zarantonello. 2009. "Brand Experience: What Is It? How Is It Measured? Does It Affect Loyalty?” Journal of Marketing 73 (5): 52-68.

Brey, E. T., D. B. Klenosky, X. Lehto, and A. M. Morrison. 2008. "Standard Hospitality Elements at Resorts: An Empirical Assessment.” Journal of Travel Research 47(2): 247-258.

Cohen, J. B. and K. Basu. 1987. “Alternative Models of Categorization: Toward a Contingent Processing Framework.” Journal of Consumer Research 13(4): 455-472.

Crompton, J. 1992. “Structure of Vacation Destination Choice Sets.” Annals of Tourism Research 19(3): 420-34.

Cruise Lines International Association. 2005. “Spring 2005 Industry Overview.” http://www.cruising.org/ press/overview/2.cfm.

Cruise Lines International Association. 2014. 2014 Cruise Manual. New York, NY: CLIA. Cruise Lines International Association. 2016. “CLIA 2016 State of the Industry Report.” http://www.cruising.org/about-the-industry/research/2016-state-of-the-industry (accessed July 23, 2016). 
Curtin, S. 2006. “Swimming with Dolphins: A Phenomenological Exploration of Tourist Recollections.” International Journal of Tourism Research 8: 301-15.

Decrop, A. and D. Snelders. 2005. “A Grounded Typology of Vacation Decision-Making.” Tourism Management 26(2): 121-32.

Everitt, B., S. Landau, and M. Leese. 2001. Cluster Analysis, 4th Edition. London and New York: Arnold and Oxford University Press.

Ewing, G. and W. Haider. 1999. “Estimating What Affects Tourist Destination Choice.” In Consumer Behavior in Travel and Tourism, edited by B. J. Knutson, A. Pizam, and Y. Mansfield, 35-58. New York, NY: Haworth Press.

Fink, E. L. 2009. “The FAQs on Data Transformation.” Communication Monographs 76(4): 379-397.

Gibson, P. 2006. Cruise Operation Management. Burlington, MA: Butterworth-Heinemann. Grewal, D., M. Levy and V. Kumar. 2009. “Customer Experience Management in Retailing: An Organizing Framework.” Journal of Retailing 85 (1): 1-14.

Hanefors, M. and L. L. Mossberg. 1999. “Package Tourism and Customer Loyalty.” In Consumer Behavior in Travel and Tourism, edited by B. J. Knutson, A. Pizam, and Y. Mansfield, 85-203. New York, NY: Haworth Press.

Hill, B. J., C. McDonald, and M. Uysal. 1990. “Resort Motivations for Different Family Life Cycle Stages.” Visions in Leisure and Business 8 (4): 18-27.

Hosany S. and M. Witham. 2010. “Dimensions of Cruisers’ Experiences, Satisfaction, and Intention to Recommend.” Journal of Travel Research 49 (3): 351-64. 
Hudson, S., T. Snaith, G. A. Miller, and P. Hudson. 2001. "Distribution Channels in the Travel Industry: Using Mystery Shoppers to Understand the Influence of Travel Agency Recommendations.” Journal of Travel Research 40(2): 148-154.

Jainchill, J. 2010. “Whatever ‘Luxury’ Means, Cruise Lines Want in on It.” http://www. travelweekly.com/Cruise-Travel/Insights/Whatever-luxury-means-cruise-lines-want-in-on-it.

Johnson, D. 2006. “Providing Ecotourism Excursions for Cruise Passengers.” Journal of Sustainable Tourism 14(1): 43-54.

Josiam, B. M., T. Y. Huang, and D. L. Spears et al. 2009. “Understanding Ethic Chinese Travelers on North America Cruise Tours: Motivations, Perceptions, and Satisfaction of Cruisers.” Journal of China Tourism Research 5: 77-101.

Kang, S. K. and H. C. Hsu. 2005. “Dyadic Consensus on Family Vacation Destination Selection.” Tourism Management 26 (4): 571-582.

Kim, S. H., S. Holland, and H. S. Han. 2013. “A Structural Model for Examining how Destination Image, Perceived Value, and Service Quality Affect Destination Loyalty: a Case Study of Orlando.” International Journal of Tourism Research 15(4): 313-328.

Klenosky, D. B., C. E. Gengler and M. S. Mulvey. 1999. "Understanding the Factors Influencing Ski Destination Choice: A Means-End Analytic Approach.” In Consumer Behavior in Travel and Tourism, edited by B. J. Knutson, A. Pizam and Y. Mansfield, 59-80. New York, NY: Haworth Press.

Klenosky, D. B. and R. E. Gitelson. 1998. “Travel Agents’ Destination Recommendations.” Annals of Tourism Research 25(3): 661-674.

Kline, R. B. 2009. Principle and Practice of Structural Equation Modeling, $3^{\text {rd }}$ Edition. New York, NY: The Guilford Press. 
Konu, H., T. Laukkanen, and R. Komppula. 2011. “Using ski destination choice criteria to segment Finnish ski resort customers.” Tourism Management 32(5): 1096-1105.

Kozinets, R. V. 2002. “Can Consumers Escape the Market? Emancipatory Illuminations from Burning Man.” Journal of Consumer Research 29 (1): 20-38.

Kwortnik, R. J. 2006. “Carnival Cruise Lines: Burnishing the Brand.” Cornell Hotel and Restaurant Administration Quarterly 47 (8): 286-300.

Lee, M. K. and S. H. Yoo. 2015. "Using a Choice Experiment (CE) to Value the Attributes of Cruise Tourism.” Journal of Travel and Tourism Marketing 32(4): 416-427.

McGarty, C. 1999. Categorization in Social Psychology. Thousand Oaks, CA: Sage.

McNamara, G. M., R. A. Luce, and G. H. Tompson. 2002. "Examining the Effect of Complexity in Strategic Group Knowledge Structures on Firm Performance.” Strategic Management Journal 23(2): 153-170.

Medin, D. L. and M. M. Schaffer. 1978. “Context Theory of Classification Learning.” Psychological Review 85(3): 207-238.

Medin, D. L. and E. E. Smith. 1984. “Concepts and Concept Formation.” Annual review of psychology 35(1): 113-138.

Mervis, C. B. and E. Rosch. 1981. “Categorization of Natural Objects.” Annual Review of Psychology 32(1): 89-115.

Meyer, C. and A. Schwager. 2007. “Understanding Customer Experience.” Harvard Business Review 85 (2): 116-26.

Mohlin, E. 2014. “Optimal Categorization.” Journal of Economic Theory 152: 356-81. 
Moscardo, G. and P. Pearce. 2003. "Life Cycle, Tourist Motivation and Transport: Some Consequences for the Tourist Experience.” In Tourism and Transportation: Issue and Agenda for the New Millennium, edited by L. Lumsdon and S. Page, 29-43. Oxford, UK: Elsevier. Murphy, L., P. Benckendorff, and G. Moscardoa. 2007. "Linking Travel Motivation, Tourist Self-Image and Destination Brand Personality.” Journal of Travel and Tourism Marketing 22(2): 45-59.

Nicolau, J. L. and F. J. Más. 2006. “The Influence of Distance and Prices on the Choice of Tourist Destinations: The Moderating Role of Motivations.” Tourism Management 27 (5): 982-996.

Ormiston, D., A. Gilbert, and R. E. Manning. 1998. “Indicators and Standards of Quality for Ski Resort Management.” Journal of Travel Research 36(1): 35-41.

Petrick, J. F. 2004. “Are Loyal Visitors Desired Visitors?” Tourism Management 25: 463-470.

Pine, B. J., and J. H. Gilmore. 1999. The Experience Economy: Work Is Theatre and Every Business A Stage. Boston, MA: Harvard Business School Press.

Punj, G. and D. W. Stewart. 1983. "Cluster Analysis in Marketing Research: Review and Suggestions for Application.” Journal of Marketing Research 20 (2): 134-48.

Porac, J. F. and H. Thomas. 1990. "Taxonomic Mental Models in Competitor Definition.” Academy of Management Review 15(2): 224-240.

Porac, J. F., H. Thomas, and C. Baden-Fuller. 1989. “Competitive Groups as Cognitive Communities: The Case of Scottish Knitwear Manufacturers.” Journal of Management Studies 26(4): 397-416.

Porac, J. F., H. Thomas, F. Wilson, D. Paton, and A. Kanfer. 1995. "Rivalry and the Industry Model of Scottish Knitwear Producers.” Administrative Science Quarterly 40(2): 203-227. 
Rao, H., P. Monin, and R. Durand. 2005. "Border Crossing: Bricolage and the Erosion of Categorical Boundaries in French Gastronomy.” American Sociological Review 70: 968-91.

Rao, R. V. and J. H. Steckel. 1998. Analysis for Strategic Marketing. Reading, MA: AddisonWesley.

Reed, S. K. 1972. “Pattern Recognition and Categorization.” Cognitive Psychology 3(3): 382407.

Rosch, E. H. 1973. “Natural Categories.” Cognitive Psychology 4(3): 328-350.

Rosch, E. H. 1978. “Principles of Categorization.” In Cognition and Categorization, edited by E. H. Rosch and B. Lloyd, 28-49. Hillsdale, NJ: Erlbaum.

Rosch, E. H. and C. B. Mervis. 1975. "Family Resemblances: Studies in the Internal Structure of Categories.” Cognitive Psychology 7(4): 573-605.

Schmitt, B. H. 1999. Experiential Marketing. New York, NY: Library of Congress Cataloguingin-Publication Data.

Sirakaya, E., A. G. Sheppard, and R. W. McLellan. 1997. “Assessment of the Relationship between Perceived Safety at a Vacation Site and Destination Choice Decisions: Extending the Behavioral Decision-Making Model.” Journal of Hospitality and Tourism Research 21(2): $1-10$.

Smith, E. E. and D. L. Medin. 1981. Categories and Concepts. Cambridge, MA: Harvard University Press.

Smith, M. C. and K. J. Mackay. 2001. “The Organization of Information in Memory for Pictures of Tourist Destinations: Are There Age-related Differences.” Journal of Travel Research 39 (3): 261-267. 
Swarbrooke, J. and S. Horner. 2007. Consumer Behavior in Tourism, $2^{\text {nd }}$ Edition. Oxford, UK: Elsevier Ltd.

Thomas, C. 2014. “W Hotels Brand Evolution.” Presented at Cornell University, School of Hotel Administration, Ithaca, NY, April 28.

Verhoef, P. C., K. N. Lemon and A. Parasuraman et al. 2009. “Customer Experience Creation, Determinants, Dynamics, and Management Strategies.” Journal of Retailing 85 (1): 31-41.

Vergne, J. P. and T. Wry. 2014. “Categorizing Categorization Research: Review, Integration, and Future Directions.” Journal of Management Studies 51 (1): 56-94.

Woodside, A. G. and S. Lysonski. 1989. “A General Model of Traveler Destination Choice.” Journal of Travel Research 27 (4): 8-14.

Zuckerman, E. W. 1999. “The Categorical Imperative: Securities Analysts and the Illegitimacy Discount.” American Journal of Sociology 104(5): 1398-1438. 


\section{Table 1: Marketer-defined Categorization for Cruise Lines}

Category and Cruise Lines

\author{
Contemporary \\ Carnival Cruise \\ Lines; \\ Costa Cruises \\ Disney Cruise Line \\ MSC Cruises \\ Norwegian Cruise \\ Line \\ Royal Caribbean \\ Cruise Line
}

\section{Premium \\ Celebrity Cruises \\ Cunard Line \\ Holland America \\ Line \\ Oceania Cruises \\ Princess Cruises}

\section{Luxury \\ Azamara Club Cruises \\ Crystal Cruises \\ Paul Gauguin \\ Cruisess \\ Pearl Seas Cruises \\ Regent Seven Seas Cruises \\ SeaDream Yacht \\ Club}

Silversea Cruises

Seabourn Cruise Line

Specialty
American Cruise
$\quad$ Lines
Avalon Waterways
Hurtigruten
Tauck River Cruises
Uniworld Boutique
$\quad$ River Cruises
Viking River Cruises
Windstar Cruises

\$250- Diverse service levels; limited

$\$ 750$

dining options, casual, less-

regimented atmosphere; focus on

destinations inaccessible to larger

ships, rivers, and inland waterways.

\author{
Ship Size \\ Target Market \\ Mainstream \\ (mass market) \\ vacationers, \\ first-time \\ cruisers, \\ families, multi- \\ generational
}

\$250- High-quality service, fine dining, a semi-formal (country club) atmosphere - though less formal than most luxury cruises, spa facilities, ample entertainment, art collections, live music, and mix of popular and less-traveled destinations (e.g., Europe, Caribbean, Alaska).

\$400- Attentive, refined, white-glove personal service, gourmet dining, a more formal atmosphere, cultured activities, and exotic itineraries (Asia, Africa, Europe).

Small-Medium ships carrying less than 1,000 passengers, typically older ships with high-quality décor and furnishings, greater space per passenger
Discerning, affluent, older, well-traveled clientele.
Small ships (yachts, Veteran masted sailing vessels replica paddle-wheeler ships, rivers boats) carrying less than 500 passengers cruisers, noncruise travelers, adventurers, affluent, older, empty nesters.

Adapted from Kwortnik (2006) 


\section{Table 2: Frequency Distribution and Descriptive Statistics of the Key Variables}

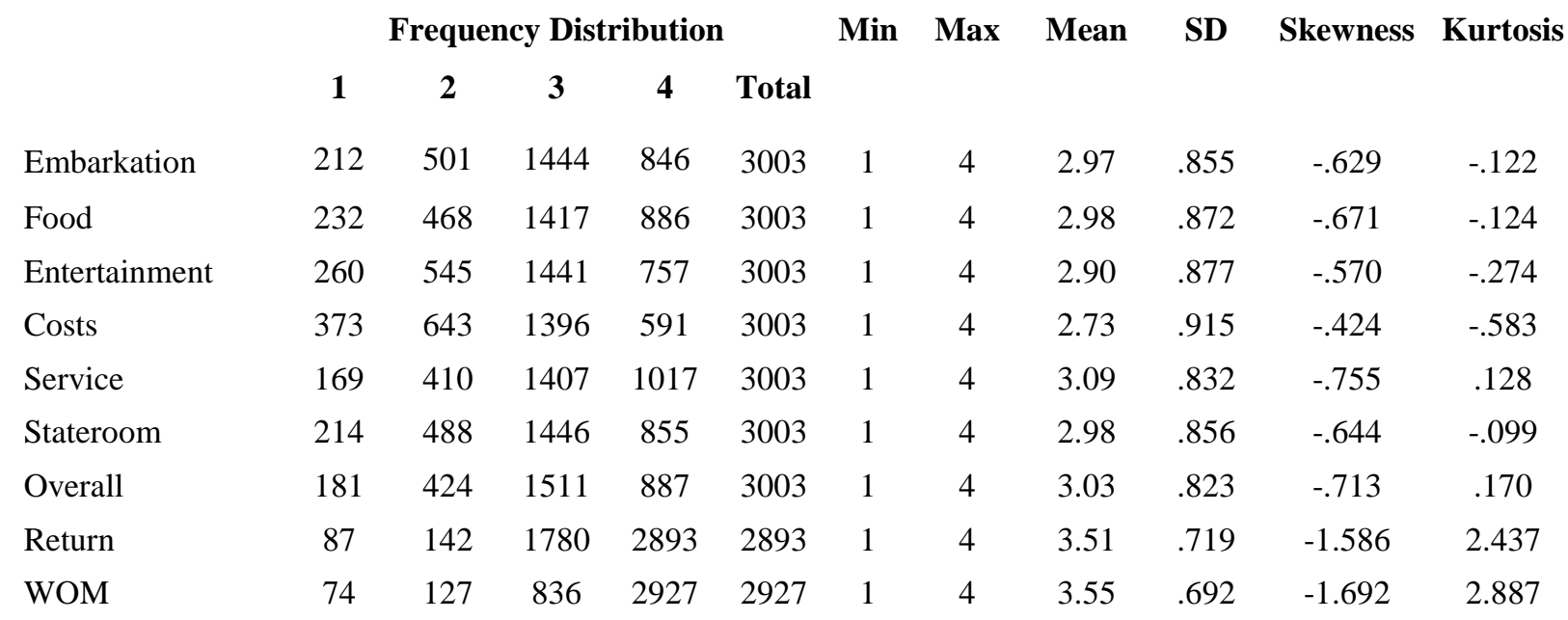

Note: To reduce the skewness, cruise experience variables were transformed from 10-points scales into 4-point scales. 
Table 3: Comparisons between Marketer-defined and Customer-derived Categorization

Marketer-defined Categories
Contemporary
Carnival
Norwegian
Royal Caribbean
Disney
Premium
Celebrity
Princess
Holland America

\begin{tabular}{cc}
\multicolumn{2}{c}{ Customer-derived Categories } \\
Category a (Standard) & Distance \\
Carnival & 0.120 \\
Norwegian & 0.095 \\
Princess & 0.070
\end{tabular}

Category b (Premium)

Royal Caribbean

0.121

Celebrity

0.093

Holland America

0.107

\section{Category c (Extraordinary)}

Disney

0.00

Note: Results for the customer-derived categories are based on a K-Means cluster analysis using experience scores. 
Table 4: Comparisons of Means of Experience-related Variables by Cruise Line Categories

\begin{tabular}{lcccccccccc}
\multicolumn{1}{c}{ Experiences } & \multicolumn{3}{c}{ Marketer-defined Categories } & \multicolumn{4}{c}{ Customer-derived Categories } \\
& \multicolumn{1}{c}{$\boldsymbol{M}_{\text {Con. }}$} & $\boldsymbol{M}_{\text {Pre. }}$ & $\boldsymbol{F}$ & $\boldsymbol{p}$ & $\boldsymbol{M}_{\text {Sta. }}$ & $\boldsymbol{M}_{\text {Pre. }}$ & $\boldsymbol{M}_{\text {Exc. }}$ & $\boldsymbol{F}$ & $\boldsymbol{p}$ \\
Embarkation & 2.971 & 2.980 & 0.073 & 0.787 & $2.924^{\mathrm{x}}$ & $2.995^{\mathrm{x}}$ & $3.131^{\mathrm{y}}$ & 8.216 & 0.000 \\
Food & 2.969 & 3.023 & 2.363 & 0.124 & $2.889^{\mathrm{x}}$ & $3.048^{\mathrm{y}}$ & $3.204^{\mathrm{z}}$ & 22.440 & 0.000 \\
Entertainment & 2.923 & 2.833 & 6.488 & 0.011 & $2.806^{\mathrm{x}}$ & $2.925^{\mathrm{y}}$ & $3.233^{\mathrm{z}}$ & 32.380 & 0.000 \\
Costs & 2.748 & 2.701 & 1.566 & 0.211 & $2.678^{\mathrm{x}}$ & $2.749^{\mathrm{x}}$ & $2.949^{\mathrm{y}}$ & 11.785 & 0.000 \\
Service & 3.083 & 3.105 & 0.434 & 0.510 & $3.005^{\mathrm{x}}$ & $3.158^{\mathrm{y}}$ & $3.236^{\mathrm{y}}$ & 16.704 & 0.000 \\
Stateroom & 2.968 & 3.008 & 1.338 & 0.247 & $2.932^{\mathrm{x}}$ & $2.992^{\mathrm{x}}$ & $3.166^{\mathrm{y}}$ & 9.970 & 0.000 \\
Overall (Self-Reported) & 3.028 & 3.048 & 0.342 & 0.559 & $2.960^{\mathrm{x}}$ & $3.077^{\mathrm{y}}$ & $3.223^{\mathrm{z}}$ & 16.112 & 0.000 \\
Overall (Factor Score) & 0.000 & -0.001 & 0.001 & 0.981 & $-0.102^{\mathrm{x}}$ & $0.050^{\mathrm{y}}$ & $0.298^{\mathrm{z}}$ & 23.583 & 0.000
\end{tabular}

Note: The superscripts $\mathrm{x}, \mathrm{y}$, and $\mathrm{z}$ represent significantly different groups in Tukey’s post-hoc tests. 


\section{Table 5: Goodness of Fit Indices of the Multi-group Structural Models}

\begin{tabular}{|c|c|c|c|c|c|c|c|c|}
\hline Models & df & $\chi^{2}$ & $\mathbf{p}$ & RMSEA & GFI & AGFI & CFI & AIC \\
\hline \multicolumn{9}{|l|}{ Measurement Models } \\
\hline Unconstrained Loading (ULM) & 27 & 46.41 & .011 & .028 & .983 & .960 & .994 & 118.41 \\
\hline Partially Constrained Loading 1 (PCL1) & 32 & 49.24 & .026 & .025 & .982 & .965 & .994 & 111.24 \\
\hline Partially Constrained Loading 2 (PCL2) & 32 & 48.98 & .028 & .024 & .982 & .965 & .994 & 110.98 \\
\hline Partially Constrained Loading 3 (PCL3) & 32 & 50.83 & .018 & .026 & .982 & .964 & .994 & 112.83 \\
\hline Equal Loading (ELM) & 37 & 52.59 & .046 & .022 & .981 & .967 & .995 & 104.59 \\
\hline \multicolumn{9}{|l|}{ Structural Regression Model } \\
\hline Unconstrained Loading (ULSR) & 69 & 103.25 & .005 & .024 & .973 & .957 & .991 & 181.25 \\
\hline Partially Constrained Loading 4 (PCL4) & 70 & 111.63 & .001 & .026 & .971 & .955 & .990 & 187.63 \\
\hline Partially Constrained Loading 5 (PCL5) & 70 & 112.48 & .001 & .026 & .970 & .954 & .989 & 188.48 \\
\hline Partially Constrained Loading 6 (PCL6) & 70 & 103.32 & .006 & .023 & .973 & .958 & .992 & 179.32 \\
\hline Equal Loading (ELSR) & 71 & 115.27 & .001 & .026 & .970 & .954 & .989 & 189.27 \\
\hline
\end{tabular}

Note: Based on the structure shown in Figure 2, the five measurement models set different restrictions on the loading weights, $\mathrm{W}_{\mathrm{ki}}$, where $\mathrm{k} \in\{2,3,4,5,6\}$ and $\mathrm{i} \in\{\mathrm{a}, \mathrm{b}, \mathrm{c}\}$. ULM sets no restrictions; PCL1 restricts $\mathrm{W}_{\mathrm{ka}}=\mathrm{W}_{\mathrm{kb}}$; PCL2 restricts $\mathrm{W}_{\mathrm{ka}}=\mathrm{W}_{\mathrm{kc}} ;$ PCL3 restricts $\mathrm{W}_{\mathrm{kb}}=\mathrm{W}_{\mathrm{kc}} ;$ ELM restricts $\mathrm{W}_{\mathrm{ka}}=\mathrm{W}_{\mathrm{kb}}=\mathrm{W}_{\mathrm{kc}}$. The five structural regression models (Fig. 3) are built on ELM, assuming the loading weights are the same for all groups, i.e., $W_{k a}=W_{k b}=W_{k c}, k \in\{2,3$, $4,5,6,8\}$. The five models set different restrictions on the regression weight $W_{7 \mathrm{i}}$, where $\mathrm{i} \in\{\mathrm{a}, \mathrm{b}, \mathrm{c}\}$. ULSR sets no restrictions; PCL4 restricts $\mathrm{W}_{7 \mathrm{a}}=\mathrm{W}_{7 \mathrm{~b}}$; PCL5 restricts $\mathrm{W}_{7 \mathrm{a}}=\mathrm{W}_{7 \mathrm{c}}$; PCL6 restricts $\mathrm{W}_{7 \mathrm{~b}}=\mathrm{W}_{7 \mathrm{c}} ;$ ELSR restricts $\mathrm{W}_{7 \mathrm{a}}=$ $\mathrm{W}_{7 \mathrm{~b}}=\mathrm{W}_{7 \mathrm{c}}$. 


\title{
Table 6: Multi-group Structural Equation Model Comparisons
}

\author{
Full Model \\ ULM \\ PCL2 \\ ULSR \\ PCL6
}

Reduced Model
PCL2
ELM
PCL6
ELSR

df
5
5
1
1

$\begin{array}{cc}\boldsymbol{\chi}^{2} & \mathbf{p} \\ 2.571 & .766 \\ 3.604 & .608 \\ 0.077 & .782 \\ 11.952 & .001\end{array}$

Note: p values larger/smaller than 0.05 suggest that the reduced/full model is better. 
Table 7: Unstandardized Parameter Estimates for the Best Models

\begin{tabular}{cccccccc} 
& Measurement Model (ELM) & \multicolumn{4}{c}{ Structural Regression Model (PCL6) } \\
Parameters & Estimates & SE & $\mathbf{p}$ & Parameters & Estimates & SE & p \\
$\mathrm{W}_{2 \mathrm{i}}$ & 1.082 & 0.043 & 0.000 & $\mathrm{~W}_{7 \mathrm{a}}$ & 0.711 & 0.057 & 0.000 \\
$\mathrm{~W}_{3 \mathrm{i}}$ & 1.063 & 0.042 & 0.000 & $\mathrm{~W}_{7 \mathrm{~b}}$ & 0.481 & 0.042 & 0.000 \\
$\mathrm{~W}_{4 \mathrm{i}}$ & 0.965 & 0.047 & 0.000 & $\mathrm{~W}_{7 \mathrm{c}}$ & 0.481 & 0.042 & 0.000 \\
$\mathrm{~W}_{5 \mathrm{i}}$ & 1.035 & 0.040 & 0.000 & & & & \\
$\mathrm{~W}_{6 \mathrm{i}}$ & 1.034 & 0.043 & 0.000 & & & &
\end{tabular}




\section{Table 8: Crosstab of Cruise Determinants by Customer-derived Cruise Line Categories}

\begin{tabular}{|c|c|c|c|c|c|c|}
\hline $\begin{array}{c}\text { Count } \\
\text { (Column \%) }\end{array}$ & $\begin{array}{l}\text { Category a } \\
\text { (Standard) }\end{array}$ & $\begin{array}{l}\text { Category b } \\
\text { (Premium) }\end{array}$ & $\begin{array}{c}\text { Category c } \\
\text { (Extraordinary) }\end{array}$ & Total & $\operatorname{Sum} \chi^{2}$ & $\begin{array}{c}\text { Cochran } \\
\text { Armitage Z }\end{array}$ \\
\hline Price & $\begin{array}{c}825 \\
(15.77)\end{array}$ & $\begin{array}{c}572 \\
(13.62)\end{array}$ & $\begin{array}{c}125 \\
(11.44)\end{array}$ & 1522 & $15.14^{*}$ & $-4.207^{*}$ \\
\hline Reputation & $\begin{array}{c}410 \\
(7.84)\end{array}$ & $\begin{array}{c}458 \\
(10.91)\end{array}$ & $\begin{array}{c}149 \\
(13.63)\end{array}$ & 1017 & $42.61^{*}$ & $6.863^{*}$ \\
\hline Past Experience & $\begin{array}{c}578 \\
(11.05)\end{array}$ & $\begin{array}{c}500 \\
(11.91)\end{array}$ & $\begin{array}{c}101 \\
(9.24)\end{array}$ & 1179 & $5.73^{*}$ & -0.618 \\
\hline Positive Review & $\begin{array}{c}324 \\
(6.19)\end{array}$ & $\begin{array}{c}278 \\
(6.62)\end{array}$ & $\begin{array}{c}107 \\
(9.76)\end{array}$ & 709 & $17.5^{*}$ & $3.599^{*}$ \\
\hline Availability & $\begin{array}{c}467 \\
(8.93)\end{array}$ & $\begin{array}{c}349 \\
(8.31)\end{array}$ & $\begin{array}{c}90 \\
(8.23)\end{array}$ & 906 & 1.22 & -1.076 \\
\hline Entertainment & $\begin{array}{c}353 \\
(6.75)\end{array}$ & $\begin{array}{c}267 \\
(6.36)\end{array}$ & $\begin{array}{c}163 \\
(14.91)\end{array}$ & 783 & $92.02^{*}$ & $6.558^{*}$ \\
\hline Recommendation & $\begin{array}{c}192 \\
(3.67)\end{array}$ & $\begin{array}{c}187 \\
(4.45)\end{array}$ & $\begin{array}{c}40 \\
(3.66)\end{array}$ & 419 & 3.91 & -0.511 \\
\hline Itinerary & $\begin{array}{c}573 \\
(10.95)\end{array}$ & $\begin{array}{c}507 \\
(12.07)\end{array}$ & $\begin{array}{c}65 \\
(5.95)\end{array}$ & 1145 & $29.98^{*}$ & $-2.703^{*}$ \\
\hline Sail Dates & $\begin{array}{c}569 \\
(10.88)\end{array}$ & $\begin{array}{c}448 \\
(10.67)\end{array}$ & $\begin{array}{c}74 \\
(6.77)\end{array}$ & 1091 & $15.31^{*}$ & $-3.155^{*}$ \\
\hline Casual Cruising & $\begin{array}{c}412 \\
(7.87)\end{array}$ & $\begin{array}{c}184 \\
(4.38)\end{array}$ & $\begin{array}{c}83 \\
(7.59)\end{array}$ & 679 & $46.51^{*}$ & $-3.680^{*}$ \\
\hline Trip Length & $\begin{array}{c}529 \\
(10.11)\end{array}$ & $\begin{array}{c}449 \\
(10.69)\end{array}$ & $\begin{array}{c}96 \\
(8.78)\end{array}$ & 1074 & 3.19 & -0.511 \\
\hline Total & $\begin{array}{l}5232 \\
(100)\end{array}$ & $\begin{array}{l}4199 \\
(100)\end{array}$ & $\begin{array}{l}1093 \\
(100)\end{array}$ & 10524 & $273.12^{*}$ & - \\
\hline
\end{tabular}


Table 9: Crosstab Analysis of Cruise Determinants by Marketer-defined Cruise Line Categories

\begin{tabular}{|c|c|c|c|c|}
\hline \multirow{2}{*}{$\begin{array}{c}\text { Count } \\
\text { (Column \%) }\end{array}$} & \multicolumn{2}{|c|}{ Cruise Line Categories } & \multirow[b]{2}{*}{ Total } & \multirow[b]{2}{*}{ Sum $\chi^{2}$} \\
\hline & Contemporary & Premium & & \\
\hline Price & $\begin{array}{c}871 \\
(13.32)\end{array}$ & $\begin{array}{c}651 \\
(16.33)\end{array}$ & 1522 & $15.51^{*}$ \\
\hline Reputation & $\begin{array}{c}682 \\
(10.43)\end{array}$ & $\begin{array}{c}335 \\
(8.40)\end{array}$ & 1017 & $10.52^{*}$ \\
\hline Past Experience & $\begin{array}{c}718 \\
(10.98)\end{array}$ & $\begin{array}{c}461 \\
(11.57)\end{array}$ & 1179 & 0.75 \\
\hline Positive Review & $\begin{array}{c}469 \\
(7.17)\end{array}$ & $\begin{array}{c}240 \\
(6.02)\end{array}$ & 709 & $4.88^{*}$ \\
\hline Availability & $\begin{array}{c}555 \\
(8.49)\end{array}$ & $\begin{array}{c}351 \\
(8.81)\end{array}$ & 906 & 0.29 \\
\hline Entertainment & $\begin{array}{c}538 \\
(8.23)\end{array}$ & $\begin{array}{c}245 \\
(6.15)\end{array}$ & 783 & $14.43^{*}$ \\
\hline Recommendation & $\begin{array}{c}247 \\
(3.78)\end{array}$ & $\begin{array}{c}172 \\
(4.32)\end{array}$ & 419 & 1.79 \\
\hline Itinerary & $\begin{array}{c}694 \\
(10.61)\end{array}$ & $\begin{array}{c}451 \\
(11.31)\end{array}$ & 1145 & 1.11 \\
\hline Sail Dates & $\begin{array}{c}643 \\
(9.83)\end{array}$ & $\begin{array}{c}448 \\
(11.24)\end{array}$ & 1091 & $4.71^{*}$ \\
\hline Casual Cruising & $\begin{array}{c}454 \\
(6.94)\end{array}$ & $\begin{array}{l}225 \\
(5.64)\end{array}$ & 679 & $6.48^{*}$ \\
\hline Trip Length & $\begin{array}{c}667 \\
(10.20)\end{array}$ & $\begin{array}{c}407 \\
(10.21)\end{array}$ & 1074 & 0.00 \\
\hline Total & $\begin{array}{l}6538 \\
(100)\end{array}$ & $\begin{array}{l}3986 \\
(100)\end{array}$ & 10524 & \\
\hline
\end{tabular}




\section{Figure 1: Marketer-defined and Customer-derived Categorizations}

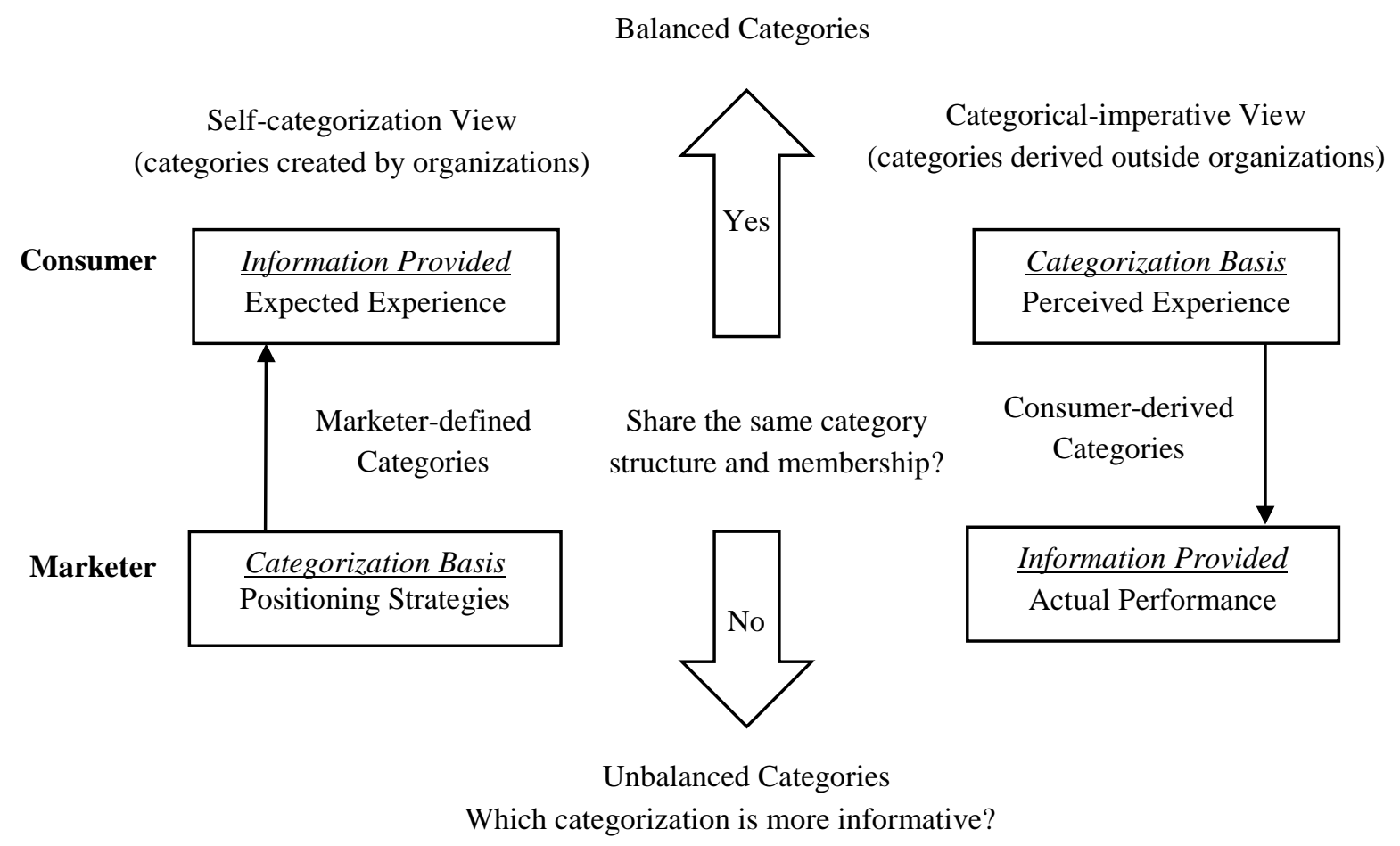


Figure 2: Multi-group Structural Equation Measurement Model for Cruise Experience

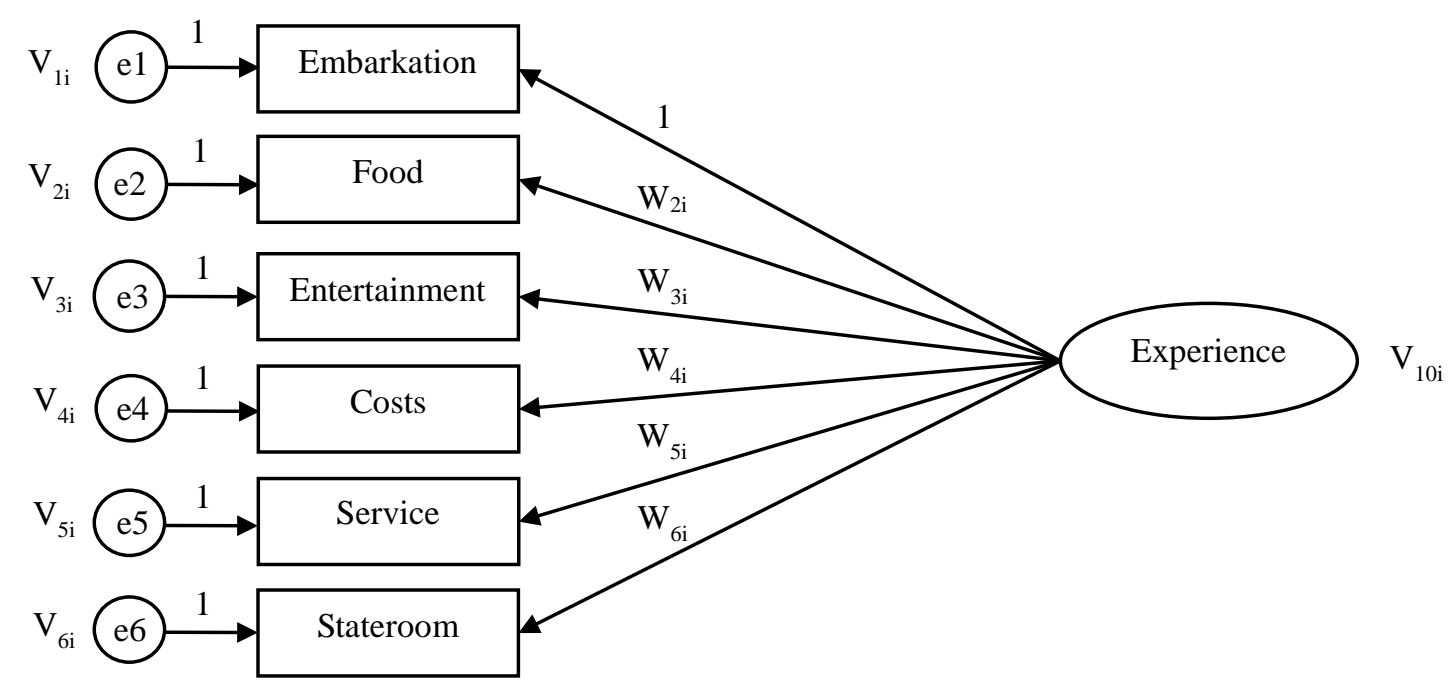

Note: $\mathrm{W}_{\mathrm{ki}}$ represents loading weights, where $\mathrm{k} \in\{2,3,4,5,6\}$ is the loading path number, and $\mathrm{i} \in\{\mathrm{a}, \mathrm{b}, \mathrm{c}\}$ is the category code. e1 through e6 are the error terms, and $V_{1 \mathrm{i}}$ through $\mathrm{V}_{6 \mathrm{i}}$ are the variances of these error terms. $\mathrm{V}_{10 \mathrm{i}}$ is the variance of the latent exogenous variable, cruise experience. 
Figure 3: Multi-group Structural Regression Model for Impact of Cruise Experience on Cruise Behavioral Loyalty

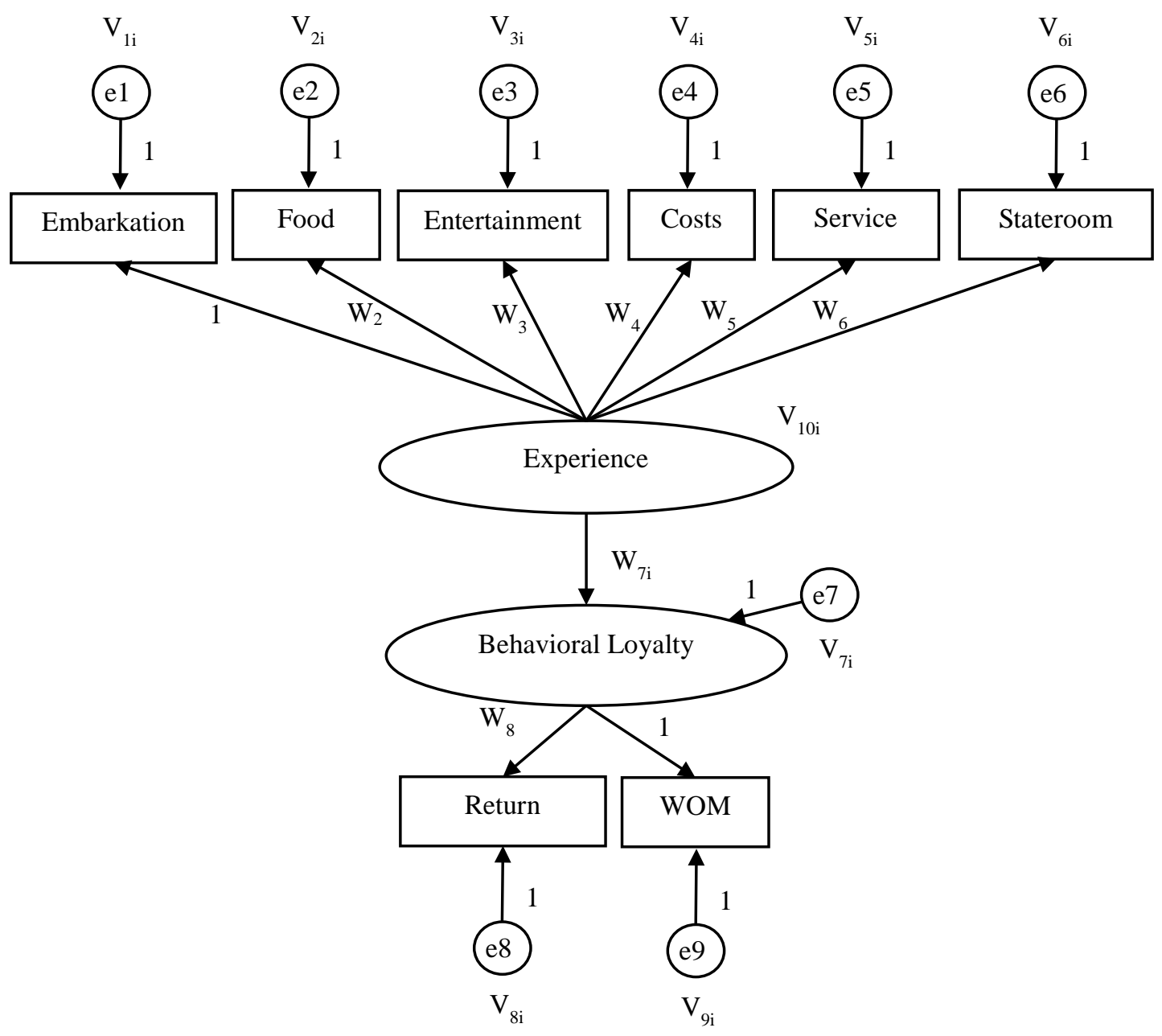

Note: $\mathrm{W}_{\mathrm{k}}$ represents loading weights, where $\mathrm{k} \in\{2,3,4,5,6,8\}$ is the loading path number. $\mathrm{W}_{7 \mathrm{i}}$ is the regression weight, where $i \in\{a, b, c\}$ is the category code. e1 through e9 are the error terms, and $V_{1 i}$ through $V_{9 i}$ are the variances of these error terms. $V_{10 i}$ is the variance of the latent exogenous variable, cruise experience. 